F. Reprod. Fert. (1975) 42, 325--333

\title{
PLASMA LUTEINIZING HORMONE LEVELS AND TESTIS DIAMETERS OF RAM LAMBS OF DIFFERENT BREEDS
}

\author{
W. R. GARR AND R. B. LAND \\ ARC Animal Breeding Research Organisation, \\ West Mains Road, Edinburgh EH9 $37 Q$
}

(Received 12th Fuly 1974)

\begin{abstract}
Summary. Plasma LH levels were examined at $1 \frac{1}{2}$-hr intervals in ram lambs of the Finnish Landrace, Border Leicester and Cheviot breeds on three occasions at 3-week intervals by radioimmunoassay. On each occasion, the mean plasma LH concentration was found to be significantly higher in the Finnish Landrace than the other two breeds, although big variations occurred between individual samples in the same animal. This form of hormonal pulsatile release was most marked in the Finnish Landrace lambs. Testis growth was also measured and was found to be correlated, independently of body weight, with LH concentration on the final sampling occasion.
\end{abstract}

\section{INTRODUCTION}

The secretion of $\mathrm{LH}$ in the ewe has been found to be breed-dependent, and related to the ovulation rate (Land, Crighton \& Lamming, 1972; Land, Pelletier, Thimonier \& Mauléon, 1973). Breed differences in ewe prolificacy are associated with differences in the ovarian activity of 1-day-old female lambs (Land, 1970a) and in the libido of males (Land, 1970b). It is possible, therefore, that breed differences in LH secretion occur in young lambs of both sexes, and that plasma LH concentrations may be indicative of subsequent female prolificacy, and of the prolificacy of a male's potential daughters.

Plasma LH was detected in the young Ile-de-France lambs (Land, Thimonier \& Pelletier, 1970) and subsequent studies with the highly prolific RomanovPréalpe cross and the pure bred Préalpe showed that differences occurred in plasma LH levels. There was a greater increase in plasma LH concentrations in males between 4 and 11 weeks of age in crossbred lambs than in pure bred Préalpes (Thimonier, Pelletier \& Land, 1972). A similar relationship between plasma LH concentration and ewe prolificacy has also been observed within the Merino breed (Bindon, 1973), in which both male and female lambs of a genetically selected flock with a high twinning rate have a greater concentration than those of flocks with a low twinning rate.

The potential usefulness of plasma LH concentration as an indication of the prediction of reproductive performance deserves further investigation, and in view of the large variation in plasma LH reported by Katongole, Naftolin \& 
Short (1974) in the ram, this characteristic has been studied in ram lambs of breeds of differing female prolificacy, with particular reference to the magnitude and frequency of the variations. The object of the study, however, was to test the hypothesis that genetic differences in prolificacy can be detected in young males rather than to describe the dynamics of plasma LH precisely.

Testis growth was also measured to study the hypothesis that it may be related to plasma LH concentration and to the prolificacy of female relatives (Land, 1973).

\section{MATERIALS AND METHODS}

Five Finnish Landrace, six Cheviot and three Border Leicester ram lambs were used. The Cheviots and the Border Leicesters were not weaned at the time of the first sampling but were weaned immediately thereafter. The lambs were housed for the course of the experiment isolated from other sheep and fed $0.9 \mathrm{~kg}$ concentrates/day/head at 07.00 hours and 16.00 hours. Hay was supplied freely.

Samples were obtained from the animals on three occasions separated by 3 weeks. On each of these sampling dates, about $7 \mathrm{ml}$ jugular vein blood was collected at $1 \frac{1}{2}-\mathrm{hr}$ intervals in evacuated heparinized tubes. This procedure was chosen to sample the plasma profile of the animals with minimum stress rather than to describe the detailed changes in hormone concentration with time. Indwelling catheters and remote collections were discounted due to their unsuitability for large-scale genetic studies. For the first two periods, eight samples were collected from each animal. For the last period, sixteen samples were collected from each animal so that, on this occasion, sampling covered 24 hr. The first collections were at 08.00 hours. The mean age of the animals of each breed was 62, 46 and 48 days for the Finnish Landrace, Cheviot and Border Leicester, respectively, at the time of the first sampling in May 1972.

The testis diameter was measured by the method described by Land (1973) and the animals were weighed at each sampling date.

The blood samples were transferred to an ice-cold bath immediately after collection until all the animals had been bled. They were then centrifuged at $4^{\circ} \mathrm{C}$, and the plasma was removed and stored at $-20^{\circ} \mathrm{C}$ until assay.

Luteinizing hormone was determined by a double antibody radioimmunoassay using an equine (anti-bovine $\mathrm{LH}$ ) antiserum and a preparation of ovine pituitary LH purified in our laboratories and labelled with ${ }^{125} \mathrm{I}$. Rabbits were immunized with horse IgG to provide precipitating antiserum. Working dilutions of this and carrier non-immune horse serum were adjusted to give optimum values. The techniques generally used were those described by Hunter (1973). The antigen was labelled by a chloramine-T method modified from that of Greenwood, Hunter \& Glover (1963). The reference preparation, NIHLH-S17, was used as standard. The purified LH preparation used as label was found to have a relative potency of $1 \cdot 6$, and behaved in an identical manner to the M3 preparation of Jutisz \& Courte (1968) in the assay.

The specificity of the assay was examined by checking against NIH-TSH-S6 (thyroid-stimulating hormone, TSH), NIH-FSH-S9 (follicle-stimulating hor- 
mone FSH) NIH-P-S9 (prolactin), NIH-GH-S10 (growth hormone, GH). The radioimmunoassay results and the specificity tests were computed using a programme derived from that of Rodbard \& Lewald (1970) which gave the estimated potency and $95 \%$ confidence intervals for each sample. The unknown plasma samples were assayed at three different dilutions and in the course of the analysis, tests were made for: (1) the linearity of the unknown curve; (2) the non-null regression of the unknown curve; (3) parallelism of unknown and standard curve; (4) homogeneity of the variance of the unknown samples and the standards.

Generally, good agreement was obtained in these tests for the plasma samples compared with the standard. The tests for specificity showed that crossreaction with TSH was important. The Endocrine Study Section reported that the NIH-TSH-S6 was contaminated with $\mathrm{LH}$, giving an unweighted geometric mean potency of $0.021 \mathrm{NIH}-\mathrm{LH}-\mathrm{Sl}$ units $/ \mathrm{mg}$, but the mean potency detected in the radioimmunoassay was $0.59 \mathrm{NIH}-\mathrm{LH}-\mathrm{S} 17$ units $/ \mathrm{mg}(95 \%$ confidence limits 0.56 to 0.62 ). Regression analysis showed good agreement for both linearity and parallelism with the standard curve. This degree of cross-reaction with TSH suggested that TSH and LH in this immunological system were similar, but the NIH preparation of TSH was treated with hydrogen peroxide to destroy the $\mathrm{LH}$, and whilst this may be successful biologically, it may not destroy the immunological activity. Confirmation of this hypothesis was obtained by collecting blood samples continuously for $2 \mathrm{hr}$ from a ram injected intravenously with $100 \mu \mathrm{g}$ thyroid-stimulating hormone releasing hormone (TRH, Hoechst) and testing the plasma obtained from 6-min blood fractions. No appreciable change in plasma $\mathrm{LH}$ was detected when a large increase in plasma TSH would be expected. The validity of the assay was further tested by assaying for $\mathrm{LH}$ sequential plasma samples taken from ovariectomized ewes treated with oestradiol. Typical peak values were obtained similar to those described by Pelletier \& Signoret (1969). The observed 'cross-reaction' therefore appeared to be an artefact, rather than a representation of the measurement of plasma TSH. The FSH and GH preparations tested gave values of 0.02 and 0.019 NIH-LHS17 units/mg which was similar to the reported contamination, although, in these cases, very poor parallelism with the standard curve was noted. No crossreaction with prolactin was detected at levels as high as $60 \mathrm{ng} / \mathrm{ml}$.

The Scatchard plot (Scatchard, 1949) was derived for the standard LH preparation used in these assays, and was found to give an hyperbola. A simple first-order chemical reaction was therefore not obtained, and at least two affinity constants were involved.

The effect of blood plasma on the assay was studied with plasma from hypophysectomized sheep containing added exogenous $\mathrm{LH}$ in various quantities. This caused a marked change in the slope of the dose-response curve. Consequently, all assays were carried out in a diluent containing bovine serum, which had been checked for very low levels of $\mathrm{LH}$, obtained from cows within 2 weeks of parturition (Carr, 1971). In these circumstances, the plasma effect was small compared with normal baseline levels of plasma LH detected in the lambs. The gradients of the unknown curves were generally less than those for the standards, even with added bovine serum, resulting in a plasma effect of 10 to 
$20 \%$ at the higher concentrations that the lower baseline levels of plasma $\mathrm{LH}$ demanded.

All the blood samples were assayed approximately by a rapid coated-tube method based on that of Goding, Catt, Brown, Kaltenbach, Cumming \& Mole (1969) before allocating three dilutions for the double antibody method, so that they fell as far as possible in the steep portion of the dose-response curve. Ten standard dilutions of the NIH preparation were prepared in triplicate (or more), covering the optimum range of response, as indicated by the computer programme. This fell between 0.1 and $4.0 \mathrm{ng}$ NIH-LH-S17/ml. Assays normally contained two batches of standards so that checks for within-assay drift could be carried out. The minimum detectable dose in most assays was $50 \mathrm{pg} /$ tube or less, so that plasma LH levels less than $0.5 \mathrm{ng} / \mathrm{ml}$ were reported as $0.5 \mathrm{ng} / \mathrm{ml}$.

All blood samples collected on each sampling occasion were assayed for plasma LH within one assay to eliminate any effect of between-assay variation.

\section{RESULTS}

The data were analysed in two parts. Firstly, the variation in plasma LH concentration was examined within and between breeds and individuals. Secondly, the association between the mean plasma $\mathrm{LH}$ concentration on each of the occasions, body weight and testis diameter was studied between the three breeds and among animals within the breeds.

\section{Differences between and within breeds}

Considerable variation in plasma LH levels in sequential samples was apparent in each breed. This is demonstrated graphically, in Text-figs 1(a), (b) and (c) which show the sequential plasma LH concentrations for three representative animals of each breed on the final sampling occasion when blood samples were collected for $24 \mathrm{hr}$. Similar variation occurred in the remaining animals on each of the sampling occasions. No suggestion of circadian or diurnal variations could be detected and the variations obtained, when examined in the context of all animals and all samples, appeared to occur at random. Any stress effects resulting from the sampling could be expected to be obtained in all the animals. It will be noted that this variation was most marked in the Finnish Landrace, slightly less in the Cheviot and only sporadic in the Border Leicester. This variation between and within types was investigated by the use of an hierarchical or nested analysis of variance which was balanced by excluding the last eight samples on the final occasion.

The mean plasma LH concentrations for each breed are given in Table 1, together with the within-ram mean squares on each sampling occasion. The heterogeneity of the within-breed variances was confirmed by the large range in mean squares (17-fold) which invalidated the assumption of equal variance. This heterogeneity was reduced markedly by the use of a $\log _{e}$ transformation (Table 2). All analyses were therefore conducted on transformed data, and the between- and within-breed mean squares are given in Table 2. On each occasion, the plasma LH concentration was found to differ significantly between the three types $(P<0.05)$, with the highest concentration in the plasma of the 
Finnish Landrace (Table 1). There was a significant difference $(P<0.01)$ between rams within breeds on the second sampling occasion only. On the first and third sampling dates, the sums of squares between and within rams were pooled to give a combined mean square before testing for differences between breeds.

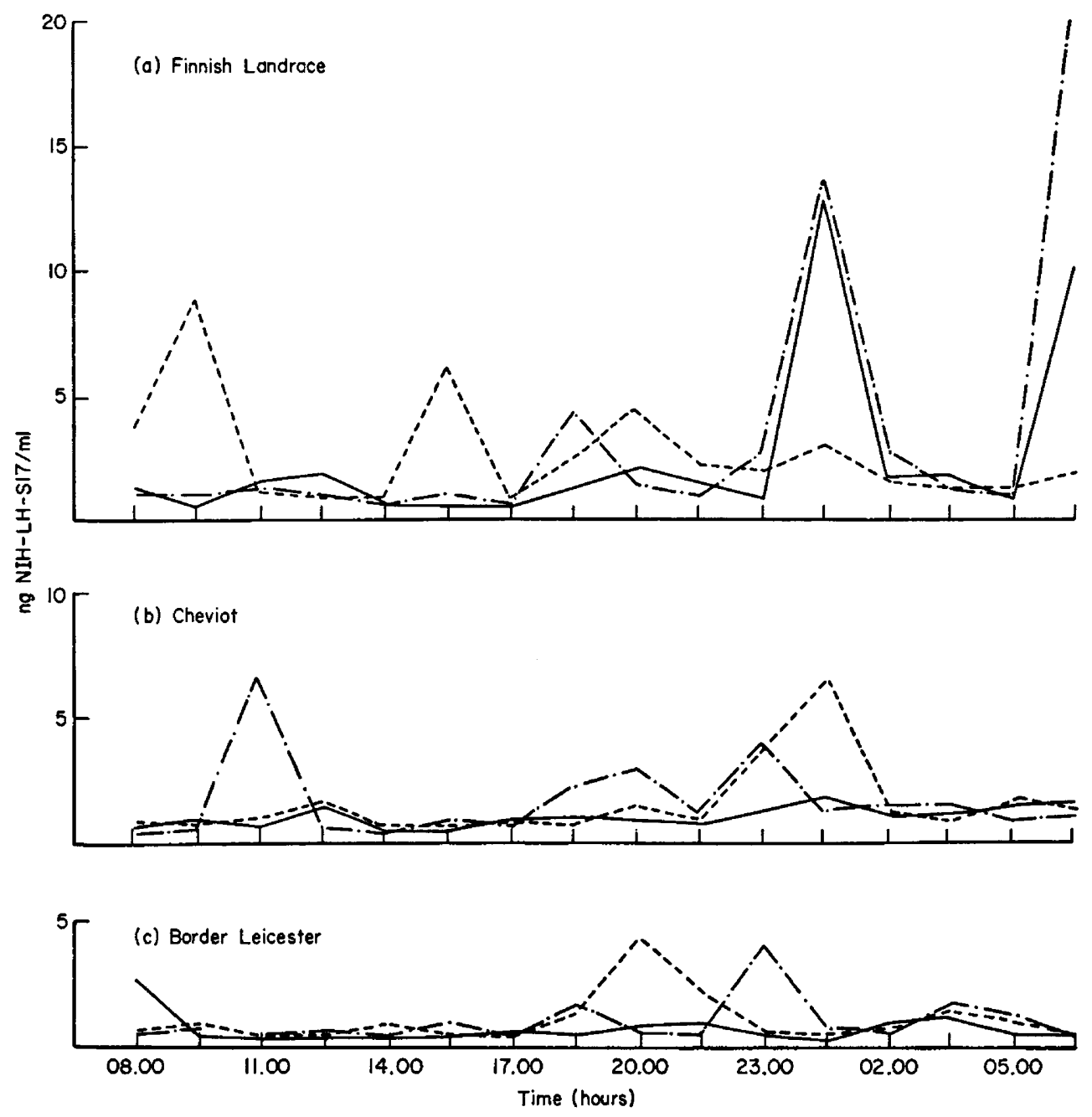

Text-Fig. 1. Plasma LH concentration of sequential blood samples taken at $1 \frac{1}{2}$-hr intervals on 29 and 30 June 1972 for three ram lambs of each breed.

Least significant differences in $\mathrm{LH}$ concentrations between the three breeds were calculated by Snedecor's modification of Tukey's method (Snedecor \& Cochran, 1967) and the plasma LH levels in the Finnish Landrace were found to be significantly higher $(P<0.05)$ than those of the other two breeds on the first and third sampling occasions. No statistically significant differences were detected between the Cheviots and Border Leicesters. 
The breed and animal differences could be derived from a number of factors including changes in the frequency or characteristics of the pulsatile release of LH. Increases in mean level of plasma LH could be caused by both increases in either the magnitude or the frequency of such releases. Changes in baseline levels would have a large effect on mean concentrations only when very few pulses occur. The frequency distribution of plasma $\mathrm{LH}$ concentration of all the samples taken in daylight hours on all three occasions is shown in Text-fig. 2 for the three breeds. The distribution curve shows that both the frequency and size of the pulsatile releases were greater in the Finnish Landrace breed. If an

Table 1. Plasma LH concentration of each of the three breeds of ram lamb on each sampling occasion

\begin{tabular}{|c|c|c|c|c|c|}
\hline $\begin{array}{c}\text { Sampling } \\
\text { occasion }\end{array}$ & Breed & $\begin{array}{l}\text { No. of } \\
\text { lambs }\end{array}$ & $\begin{array}{c}\text { No. of } \\
\text { blood } \\
\text { samples/lamb }\end{array}$ & $\begin{array}{c}\text { Mean } L H \\
\text { conc. }(n g / m l)\end{array}$ & $\begin{array}{c}\text { Mean square } \\
(\mathrm{ng} / \mathrm{ml})^{2}\end{array}$ \\
\hline 1 & $\begin{array}{l}\text { Finnish Landrace } \\
\text { Cheviot } \\
\text { Border Leicester }\end{array}$ & $\begin{array}{l}5 \\
6 \\
3\end{array}$ & $\begin{array}{l}8 \\
8 \\
8\end{array}$ & $\begin{array}{l}5 \cdot 99 \\
3 \cdot 68 \\
2 \cdot 59\end{array}$ & 16.85 \\
\hline 2 & $\begin{array}{l}\text { Finnish Landrace } \\
\text { Gheviot } \\
\text { Border Leicester }\end{array}$ & $\begin{array}{l}5 \\
6 \\
3\end{array}$ & $\begin{array}{l}8 \\
8 \\
8\end{array}$ & $\begin{array}{l}6 \cdot 22 \\
2 \cdot 85 \\
1 \cdot 32\end{array}$ & $34-25$ \\
\hline 3 & $\begin{array}{l}\text { Finnish Landrace } \\
\text { Cheviot } \\
\text { Border Leicester }\end{array}$ & $\begin{array}{l}5 \\
6 \\
3\end{array}$ & $\begin{array}{l}8 \\
8 \\
8\end{array}$ & $\begin{array}{l}1.81 \\
0.95 \\
0.63\end{array}$ & 1.98 \\
\hline
\end{tabular}

* Mean square within rams from hierarchical analysis of variance.

Table 2. The mean squares between breeds, between rams, within breeds and between samples within rams from the hierarchical analysis of variance of transformed plasma LH concentration

\begin{tabular}{|c|c|c|c|c|c|}
\hline \multirow{2}{*}{ Source of variation } & \multirow{2}{*}{ d.f. } & \multicolumn{4}{|c|}{ Sampling occasion } \\
\hline & & 1 & 2 & 3 & \\
\hline Between breeds & 2 & $7 \cdot 71^{* *}$ & $20 \cdot 01 * *$ & $6 \cdot 20^{*}$ & \\
\hline $\begin{array}{l}\text { Between rams } \\
\text { within breeds }\end{array}$ & $11\} 119$ & $\left.{ }^{0.53}\right\} 0.57$ & $2 \cdot 42 * *$ & 0.757 & 0.44 \\
\hline Within rams & 98 & 0.63 & 0.91 & 0.41 & \\
\hline
\end{tabular}

$* P<0.05 ; * * P<0.01$.

arbitrary value of $5 \mathrm{ng} / \mathrm{ml}$ plasma $\mathrm{LH}$ concentration is chosen as a threshold for pulsatile release, the proportion of samples over this threshold was 27, 13 and $6 \%$ for the Finnish Landrace, Cheviot and Border Leicester males respectively. These differences are highly significant and indicate that the higher mean LH concentration of the Finnish Landrace ram lambs arises from an increase in the frequency of $\mathrm{LH}$ pulses and increases in the size of the pulse.

On the final sampling occasion, samples were collected over a full 24-hr period and examination of the results has indicated no within-breed differences between night and daytime sampling. 


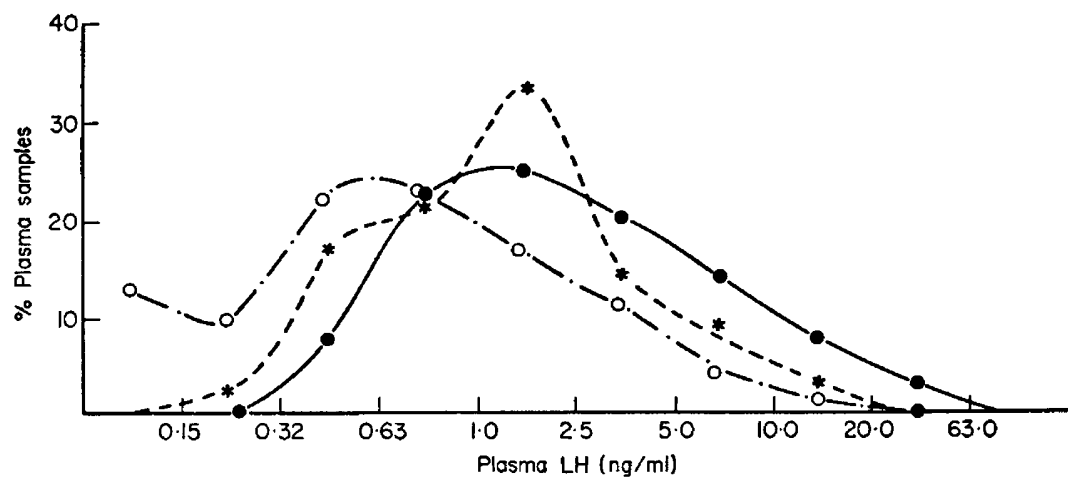

TEXT-FIG. 2. Frequency distribution curve of plasma LH concentrations of three breeds of ram lambs. -, Finnish Landrace; - - , Cheviot; - - - - Border Leicester.

\section{Relationships between LH concentration and testis size}

The mean plasma LH concentration for each ram on each sampling occasion was used to study the relationships between LH concentration, testis size and body weight. The means of the last two parameters are given for each breed in Table 3.

The within-breed correlation between these parameters was obtained from the pooled sums of squares and cross products within the three breeds. Part of the correlation matrix is shown in Table 4 and with eight degrees of freedom, correlation coefficients of 0.6 and above are statistically significant $(P<0 \cdot 05)$.

The testis diameter on the final sampling occasion was correlated with $\mathrm{LH}$ levels on both the second and final occasions with a coefficient of 0.6 and 0.7 respectively. Inspection of Table 4 indicates that testis size and body weight frequently showed a similar correlation. In order, therefore, to estimate the relation between $\mathrm{LH}$ concentration and testis diameter independently of the effect of body weight, the partial correlation was calculated, again within breeds. The coefficients are shown also in Table 4 . The value of 0.7 was not changed and indicated that half the variation in testis diameter was associated with that in $\mathrm{LH}$ concentration on the final sampling occasion, and that this association was not related to differences in body weight.

Table 3. Mean body weight and testis diameter of ram lambs on the three different sampling occasions

\begin{tabular}{|c|c|c|c|c|c|c|}
\hline \multirow[b]{2}{*}{$\begin{array}{l}\text { Sampling } \\
\text { occasion }\end{array}$} & \multirow[b]{2}{*}{ Parameter } & \multicolumn{3}{|c|}{ Breed } & \multicolumn{2}{|c|}{ Mean square } \\
\hline & & $\begin{array}{l}\text { Finnish } \\
\text { Landrace }\end{array}$ & Cheviot & $\begin{array}{c}\text { Border } \\
\text { Leicester }\end{array}$ & $\begin{array}{l}\text { Between rams } \\
\quad\left(\begin{array}{ll}2 & d . f .\end{array}\right)\end{array}$ & $\begin{array}{c}\text { Within } \\
\text { breeds } \\
\left(\begin{array}{lll}11 & d . f .\end{array}\right)\end{array}$ \\
\hline 1 & $\begin{array}{l}\text { Mean testis diam. }(\mathrm{cm}) \\
\text { Mean body wt }(\mathrm{kg})\end{array}$ & $\begin{array}{l}1 \cdot 84 \\
15 \cdot 0\end{array}$ & $\begin{array}{l}1.85 \\
17 \cdot 2\end{array}$ & $21 \cdot 84$ & $\begin{array}{c}0 \\
37 \cdot 7\end{array}$ & $\begin{array}{l}\mathbf{0 . 0 6} \\
11 \cdot 4\end{array}$ \\
\hline 2 & $\begin{array}{l}\text { Mean testis diam. }(\mathrm{cm}) \\
\text { Mean body wt }(\mathrm{kg})\end{array}$ & $20 \cdot 3$ & $\begin{array}{l}2 \cdot 00 \\
25 \cdot 8\end{array}$ & $\begin{array}{l}1 \cdot 81 \\
27 \cdot 7\end{array}$ & $\begin{array}{l}0.29 \\
62 \cdot 1\end{array}$ & $\begin{array}{l}0 \cdot 12 \\
21 \cdot 7\end{array}$ \\
\hline 3 & $\begin{array}{l}\text { Mean testis diam. }(\mathrm{cm}) \\
\text { Mean body wt }(\mathrm{kg})\end{array}$ & $\begin{array}{c}3 \cdot 03 \\
22 \cdot 0\end{array}$ & $\begin{array}{l}2 \cdot 34 \\
26 \cdot 0\end{array}$ & $28 \cdot 3$ & $\begin{array}{l}0.99 \\
42 \cdot 1\end{array}$ & $\begin{array}{l}0 \cdot 18 \\
11 \cdot 3\end{array}$ \\
\hline
\end{tabular}


Table 4. Part of the correlation matrix of testis diameter with $\mathrm{LH}$ concentration and body weight on each sampling occasion for the three breeds of ram lamb, together with the partial correlation (in parentheses) between testis diameter and LH concentration, when body weight was fixed

\begin{tabular}{|c|c|c|c|c|c|c|}
\hline \multicolumn{7}{|c|}{ Correlation coefficients of: } \\
\hline \multirow{2}{*}{$\begin{array}{l}\text { Testis diameter } \\
\text { measured on occasion: }\end{array}$} & \multicolumn{3}{|c|}{ With $L H$ concentration on occasion: } & \multicolumn{3}{|c|}{ With body weight on occasion: } \\
\hline & 1 & 2 & 3 & 1 & 2 & 3 \\
\hline 1 & $\begin{array}{c}0.2 \\
(-0.1)\end{array}$ & 0.5 & $0 \cdot 2$ & 0.8 & 0.4 & 0.7 \\
\hline 2 & 0.7 & $\begin{array}{c}0 \cdot 6 \\
(0 \cdot 3)\end{array}$ & $0 \cdot 4$ & 0.6 & $0 \cdot 6$ & 0.5 \\
\hline 3 & 0.5 & 0.6 & $\begin{array}{c}0 \cdot 7 \\
(0 \cdot 7)\end{array}$ & 0.6 & 0.4 & 0.6 \\
\hline
\end{tabular}

\section{DISCUSSION}

The pulsatile behaviour of plasma LH concentration reported by Katongole et al. (1974) in rams was also found to occur in ram lambs. In general, as the lambs approached puberty, the variation decreased.

Although Turner (1969) and Bradford (1972) reported that litter size can and has been changed by selection, the rate of response is low. One of the factors responsible for the slow progresss is that, at present, this trait is sex-limited and can only be measured in the female. This limit could be removed if a selection criterion such as plasma $\mathrm{LH}$ concentration could be established in the male, thus leading to the direct selection of males and more efficient use of selection and testing facilities. Notwithstanding the large variation of LH levels which occurred in sequential blood samples from the same animals, a breed difference in the mean plasma concentration was detected under the present conditions. The blood samples from the highly prolific breed, the Finnish Landrace, gave higher mean levels than those from the other two breeds. We are able to confirm, therefore, the between-breed findings of Thimonier et al. (1972). Furthermore, Bindon (1973) has reported a similar relationship within a breed. This suggests that there may be a genetically controlled relationship between plasma LH concentration of ram lambs and ewe prolificacy and, hence, that it may be possible to predict the reproductive performance of a ram lamb's potential offspring. The variation between samples from an individual animal is so high, however, that the value of single samples as a selection criterion must be limited, and it is possible that the study of the control of the frequency and magnitude of the pulsatile release of LH may aid the development of suitable criteria for the genetic improvement of reproductive performance.

Land (1973) has put forward the hypothesis that testis growth in the lamb may be used as a simple measure of circulating gonadotrophins and this has been tested by examining the relation between testis diameter and plasma $\mathrm{LH}$ concentration. Despite the large variations in plasma LH concentration, a significant correlation between testis diameter and mean LH concentration was 
observed for all the rams on the final sampling occasion, particularly when the effect of body weight was taken into account. A combination of testis growth and a series of plasma LH estimations may therefore form the basis of a suitable selection criterion.

\section{ACKNOWLEDGMENTS}

We wish to thank Dr R. B. Snook for the provision of the equine (anti-bovine LH) antiserum, Dr M. Jutisz for M3 purified ovine LH, Dr D. Rodbard for his computer program and the Pituitary Hormone Distribution Program of the National Institute of Health, U.S.A., for hormone preparations. We are grateful to Mr D. Morrill, Mr A. G. Wheeler, Mr R. D. Preece, Miss M. Fordyce and $\mathrm{Mr}$ A. McGregor for skilled assistance with the animals and assay, and to $\mathrm{Mr}$ A. F. Purser, Miss S. Dick, Mr D. T. Wilson and Mr D. Maxwell for computer analyses.

\section{REFERENCES}

Bindon, B. N. (1973) Genetic differences in plasma LH of the prepubertal lamb. F. Reprod. Fert. 32, 347, Abstr.

BRADFORD, G. E. (1972) Genetic control of litter size in sheep. F. Reprod. Fert., Suppl. 15, 23-41.

GARR, W. R. (1971) Serum luteinizing hormone during the pregnancy of a Zebu cow. F. Reprod. Fert. 27, 141-143.

Goding, J. R., Gatt, K. J., Brown, J. M., Kaltenbach, C. C., Cumming, I. A. \& Mole, B. J. (1969) Radioimmunoassay for ovine luteinizing hormone. Secretion of luteinizing hormone during estrus and following estrogen administration in the sheep. Endocrinology, 85, 133-142.

Greenwood, F. C., Hunter, W. M. \& GLover, J. S. (1963) The preparation of ' ${ }^{131}$ I' labelled human growth hormone of high specific radio activity. Biochem. 7. 89, 114-123.

Hunter, W. M. (1973) Radioimmunoassay. In Handbook of Experimental Immunology, 2nd edn, chap. 17, p. 10. Ed. D. M. Weir. Blackwell Scientific Publications, Oxford.

Jutrsz, M. \& Courte, C. (1968) Hormone lutéinesante (LH) de Mouton. 1. Obtention à l'état apparemment homogène. Etude physico-chimique et biologique. Gen. $\mathcal{F}$ compar. Endocr. 11, 562-574.

Katongole, G. B., Naftolin, F. \& Short, R. V. (1974) Seasonal variation in blood luteinizing hormone and testosterone levels in rams. F. Endocr. 60, 101-106.

LAND, R. B. (1970a) The number of oocytes present at birth in the ovaries of pure and Finnish Landrace cross Blackface and Welsh Sheep. J. Reprod. Fert. 21, 517-521.

LAND, R. B. (1970b) The mating behaviour and semen characteristics of Finnish Landrace and Scottish Blackface rams throughout the year. Anim. Prod. 12, 551-560.

LAND, R. B. (1973) The expression of female sex-limited characters in the male. Nature, Lond. 241, 208209.

LAND, R. B., Crighton, D. B. \& Lamming, G. E. (1972) Gonadotrophin contents of the pituitaries of sheep of differing fertility at three stages of the oestrous cycle. 7. Reprod. Fert. 30, 313-316.

Land, R. B., Pelletier, J., Thimonier, J. \& Mauléon, P. (1973) A quantitative study of genetic differences in the incidence of oestrus, ovulation and plasma luteinizing hormone concentration in the sheep. F. Endocr. 58, 305-317.

Land, R. B., Thimonier, J. \& Pelletier, J. (1970) Possibilité d'induction d'une décharge de LH par une injection d'oestrogène chez l'agneau femelle en fonction de l'âge. C. r. hebd. Séanc. Acad. Sci., Paris, 271, 1549-1551.

Pelletier, J. \& Signoret, J. P. (1969) Contrôle de la décharge de LH dans le sang par la progestérone et le benzoate d'oestradiol chez la brebis castrée. C. r. hebd. Séanc. Acad. Sci., Paris, 269, 2595-2598.

Rodbard, D. \& Lewaid, J. E. (1970) Computer analysis of radioligand assay and radioimmunoassay data. Acta endocr., Copenh. Suppl. 147, 79-103.

Scatchard, G. (1949) The attractions of proteins for small molecules and ions. Ann. N.Y. Acad. Sci. $51,660-672$.

Snedecor, G. W. \& Cochran, W. G. (1967) Statistical Methods, 6th edn. Iowa State University Press.

Thimonier, J., Pelletier, J. \& Land, R. B. (1972) The concentration of plasma LH in male and female lambs of high and low prolificacy breed types. F. Reprod. Fert. 31, 498-499.

TURner, H. N. (1969) Genetic improvement of reproductive rate in sheep. Anim. Breed. Abstr. 37, 545-563. 